\title{
PERANAN REMAJA MASJID AR-RAHMAN DALAM PEMBENTUKAN KARAKTER REMAJA YANG RELIGIUS DI DESA WAEKASAR KECAMATAN WAEAPO KABUPATEN BURU
}

\author{
Wakhidatul Khasanah, ${ }^{1}$ Samad Umarella ${ }^{2}$ Ainun Diana Lating ${ }^{2}$ \\ ${ }^{1}$ Mahasiswa PAI FITK IAIN Ambon, ${ }^{2}$ Dosen PAI FITK IAIN Ambon \\ email: wakhidatul.khasanah97@gmail.com
}

\begin{abstract}
Abstrak Hasil penelitian menunjukkan bahwa peranan remaja masjid Ar-Rahman dalam pembentukan karakter remaja yang religius di Desa Waekasar Kecamatan Waeapo Kabupaten Buru sangat berperan dengan baik dan dalam pembentukan karakter remaja yang religius dilakukan melalui pelatihan kepemimpinan, pengajian rutin, kegiatan kerohanian dibidang budaya dan mauludan dengan melibatkan pemimpin setempat yang menggerakan dan mendayagunakan potensi generasi muda dan masyarakat. Remaja masjid di waekasar setiap habis sholat magrib mengajak para remaja putra maupun putri untuk ikut mengaji bersama di masjid, membuat remaja masjid lebih dekat dengan masjid, lebih berperan dalam kegiatan keagamaan dan menjadi partisipasi sosial kemasyarakatan. Adapun kegiatan yang menjadi pembentukan karakter remaja masjid Ar-Rahman di Desa Waekasar Kecamatan Waeapo Kabupaten Buru dalam kegiatannya yang dapat membentuk karakter remaja yaitu dalam kesadaran beragama dan kerukunan beragama. Kegiatan-kegiatan remaja masjid seperti kegiatan rutinan berjanjen atau sholawat, kegiatan latihan rebana, dan setiap satu tahun melaksanakan peringatan isra mi'raj, maulid Nabi, tahun baru hijriyah.
\end{abstract}

Kata Kunci: Peranan, Remaja Masjid, Karakter Religius.

\section{PENDAHULUAN}

Masjid pada awalnya merupakan tempat pusat segala kegiatan, bukan saja sebagai pusat ibadah khusus, seperti shalat dan i'tikaf. Akan tetapi, masjid merupakan pusat kebudayaan dan muamalat. Masjid merupakan tempat dimana lahir kebudayaan Islam yang demikian kaya dan berkah (Sofan Safri Harahap, 1996). Jika berbicara tentang masjid, maka tidak terlepas dengan peran remaja masjid. Pada masa dahulu, peran remaja masjid sangatlah penting terutama dalam membentuk generasi Islam serta pembentukan karakter yang religius.

Remaja sebagai kelompok manusia yang penuh potensi, perlu diketahui bahwa pada saat ini kelompok remaja Indonesia berjumlah kurang lebih sepertiga dari penduduk bumi tercinta ini. Kelompok yang penuh potensi, dan sebagai penerus generasi bangsa (Andi Mapiare, 1982). 
Dengan adanya remaja masjid yang turut berjuang menyumbang tenaga dan pikirannya untuk memajukan kualitas agama Islam yang dimiliki masyarakat dengan melaksanakan kegiatan-kegiatan yang bersifat Islami, seperti: Diba'iyah(Diba'an dan Shalawatan), yasinan dan tahlilan, pengajian rutin, santunan anak yatim, wisata Qolbu, dan khotmil Qur'an.

Kesadaran beragama adalah menjalankan perintah agama tanpa adanya unsur keterpaksaan tetapi atas keinginannya sendiri, sedangkan kerukunan beragama adalah suatu kondisi sosial dimana semua golongan agama bisa hidup bersama-sama tanpa mengurangi hak dasar masingmasing untuk melaksanakan agama sesuai dengan keyakinannya dalam keadaan rukun dan damai (Alamsyah Ratu Perwiranegara, 1986).

Dalam kehidupan masyarakat keaktifan beribadah sangat diperlukan, mengingat keagamaan dilingkungan masyarakat cenderung dipengaruhi oleh faktor lingkungan dan kondisi kejiwaan masyarakat, bisa dikatakan bahwa lingkungan masyarakatnya agamis dan bergaul dengan orangorang yang memegang teguh keimanan maka kondisi agamanya akan berpengaruh menjadi baik dan juga sebaliknya. Maka dari itu dengan adanya kegiatan-kegiatan yang diadakan remaja masjid dapat mendorong masyarakat aktif dalam beribadah serta mengetahui tata cara, manfaat, fungsi, dan kewajiban-kewajiban yang harus dilakukan oleh masyarakat sesuai dengan ajaran Islam.

\section{TINJAUAN PUSTAKA}

\section{A. Tinjauan Tentang Remaja Masjid}

\section{Pengertian Remaja Masjid}

Masa remaja merupakan salah satu periode dari perkembangan manusia. Masa ini merupakan masa perubahan atau peralihan dari masa kanak-kanak ke masa dewasa yang meliputi perubahan biologis, perubahan psikologis, dan perubahan sosial. Remaja sering kali didefinisikan sebagai periode transisi antara masa kanak-kanak ke masa dewasa, atau masa usia belasan tahun, atau seseorang yang menunjukkan tingkah laku tertentu seperti susah diatur, mudah terangsang perasaannya dan sebagainya.

Remaja adalah mereka yang mengalami masa transisi (peralihan) dari masa kanak-kanak menuju masa dewasa, yaitu antara usia 12-13 tahun hingga usia 20-an, perubahan yang terjadi termasuk drastis pada semua aspek perkembangannya yaitu meliputi perkembangan fisik, kognitif, kepribadian, dan sosial.

Definisi remaja sendiri dapat ditinjau dari tiga sudut pandang, yaitu: 
a. Secara kronologis, remaja adalah individu yang berusia antara 11-12 tahun sampai 20-21 tahun;

b. Secara fisik, remaja ditandai oleh ciri perubahan pada penampilan fisik dan fungsi fisiologis, terutama yang terkait dengan kelenjar seksual;

c. Secara psikologis, remaja merupakan masa dimana individu mengalami perubahan - perubahan dalam aspek kognitif, emosi, sosial, dan moral, diantara masa anak-anak menuju masa dewasa.

2. Landasan BKPRMI (Badan Komunikasi Pemuda Remaja Masjid Indonesia).

Badan Komunikasi Pemuda Remaja Masjid Indonesia merupakan salah satu organisasi yang bertujuan memberdayakan dan mengembangkan potensi pemuda remaja masjid dalam upaya untuk pengembangan minat, kemampuan dan pemahaman AlQur'an bagi seluruh pemuda, remaja, dan anak-anak serta jamaah masjid. Adanya organisasi ini supaya terdorong tumbuhnya organisasi pemuda remaja dan mengkokohkan komunikasi di kalangan pemuda remaja masjid dalam rangka mengembangkan program dan kegiatan-kegiatannya (Hasil-hasil Ketetapan Masyarakat Nasional XI, 2009).

\section{Batasan Usia Remaja}

Masa remaja berlangsung antara umur 12 tahun sampai dengan 21 tahun bagi wanita dan 13 tahun sampai dengan 22 tahun bagi pria. Sedangkan pengertian remaja menurut Zakiah Darajat adalah masa peralihan diantara masa kanak-kanak dan dewasa. Dalam masa ini anak mengalami masa pertumbuhan dan masa perkembangan fisiknya maupun perkembangan psikisnya. Mereka bukanlah anak-anak baik bentuk badan ataupun cara berfikir atau bertindak, tetapi bukan pula orang dewasa yang telah matang. Batasan usia remaja yang umum digunakan oleh para ahli adalah antara 12 hingga 21 tahun. Rentang waktu usia remaja ini biasanya dibedakan atas tiga, yaitu 12 - 15 tahun = masa remaja awal, 15 18 tahun = masa remaja pertengahan, dan $18-21$ tahun = masa remaja akhir (Zakiah Darajat, 1973).

\section{Fungsi Remaja Masjid}

Keberadaan Remaja Masjid sangat berpengaruh bagi kehidupan umat Islam di sekitar masjid tersebut karena Remaja Masjid berfungsi sebagai:

a. Pelopor Kegiatan Religi, remaja masjid berperan mengkoordinasi kegiatan rohani masyarakat. 
b. Memajukan Kualitas Iman Masyarakat, mengadakan kegiatan rohani yang dapat meningkatkan kualitas iman masyarakat sekitar.

c. Sarana Dakwah dan syiar Islam kepada masyarakat, mengajak masyarakat untuk selalu beriman dan bertakwa kepada Allah SWT.

\section{Tujuan Remaja Masjid}

Dalam suatu organisasi pasti mempunyai tujuan dalam pelaksanaan kegiatan-kegiatanya. Salah satunya yaitu dalam Organisasi Remaja Masjid tujuan yang paling utama adalah mengajak masyarakat khususnya remaja-remaja secara bersamasama aktif dalam organisasi Remaja masjid ini untuk meramaikan masjid dengan kegiatan-kegiatan syar'i seperti kajian rutin, seminar, dan kegiatan positif lainnya yang seluruh kegiatannya akan diadakan di Masjid. Di samping itu organisasi Remaja Masjid juga akan mencoba mengarahkan dengan arahan yang benar menurut syara melalui pembinaan yang kontinyu (rutin) bagi para anggotanya.

Dengan demikian remaja masjid mempunyai hak untuk memakmurkan masjid dengan syarat mereka harus mempunyai jiwa yang agamis dan bersikap sesuai dengan karakteristik Islam.

Allah SWT berfirman dalam Al-Qur'an Surah At-Taubah : Ayat 18

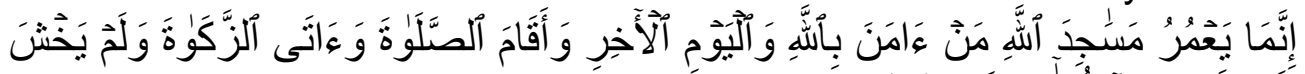

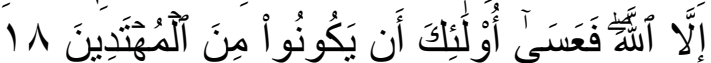

Terjemahan: "Hanya yang memakmurkan masjid-masjid Allah ialah orang-orang yang beriman kepada Allah dan Hari kemudian, serta tetap mendirikan shalat, menunaikan zakat dan tidak takut (kepada siapapun) selain kepada Allah, maka merekalah orang-orang yang diharapkan termasuk golongan orang-orang yang mendapat petunjuk".

\section{Kegiatan-kegiatan Remaja Masjid}

Berbicara mengenai kegiatan remaja masjid tidak pernah lepas dari fungsi masjid itu sendiri. Adapun fungsi masjid diantaranya adalah:

a. Masjid berfungsi sebagai tempat ibadah bagi umat Islam.

b. Masjid berfungsi sebagai pusat ilmu pengetahuan.

c. Masjid sebagai pusat peribadatan.

d. Masjid berfungsi sebagai pusat menciptakan ukhuwah Islamiyah.

e. Masjid berfungsi sebagai pusat pembinaan umat.

Melihat fungsi masjid yang telah dibahas di atas, maka di masjid perlu di adakan kegiata-kegiatan yang dapat meningkatkan 
kualitas masyarakat umat Islam. Adapun kegiatan dan daftar kegiatannya adalah sebagai berikut:

a. Kegiatan Ibadah Khusus

Masjid harus dapat menjadi tempat ibadah kepada Allah yang nyaman, aman, indah, tenang, dan selalu ramai dikunjungi jama'ah. Maka dari itu masjid harus mempunyai kegiatan-kegiatan untuk masyarakat yakni kegiatan ibadah khusus. Kegiatan ibadah khusus meliputi pelaksanaan shalat jum'at, idul fitri, idul adha (Sofyan Syafri Harahap, 2001). Kegiatan ibadah khusus biasanya di atur oleh ta'mir masjid bekerjasama dengan remas dan masyarakat setempat.

b. Kegiatan Pelatihan Kader

Kegiatan pelatihan kader adalah kegiatan yang menghasilkan kader penerus masa depan dan untuk mengeluarkan penerus yang mempunyai keahlian. Dalam kegiatan kader ini Remaja masjid mengadakan beberapa pelatihan, yaitu: workshop, pelatihan adzan, pelatihan ngaji tartil, pelatihan traning leadership, buletin, dan LDK (Latihan Dasar Kepemimpinan).

c. Kegiatan Sosial

Kegiatan sosial adalah ibadah yang menyangkut orang banyak. Jenis kegiatan sosial ini pada umunya adalah mengurus zakat, qurban, bakti sosial membantu fakir miskin, anak yatim, khitan masal, membantu anak terlantar dan sebagainya.

d. Kegiatan kesenian

Dalam kegiatan kesenian ini pada umumnya mengadakan kegiatan yang bersifat seni, di antaranya: pelatihan seni baca AlQur'an, latihan banjari, mengadakan sholawat diba', membentuk group sholawat keliling, group nasyid, remas voice (suara).

e. Kegiatan Syi'ar dan Dakwah.

Kegiatan syi'ar dan dakwah merupakan kegiatan yang paling utama atau pokok karena dalam kegiatan ini setiap ada hari besar Islam dan hari besar Nasioanl harus diperingati.

Ada beberapa hal yang mungkin dapat dijadikan motivasi untuk terus berperan aktif dalam melaksanakan aktifitas-aktifitas remaja masjid, diantaranya:

a. Kemakmuran masjid hidup matinya aktifitas ada ditanggung jawab semua umat Islam. 
b. Bagi orang-orang yang senantiasa memakmurkan masjid akan mendapatkan pahala balasan surga dari Allah kelak pada hari kiamat.

Sebagaimana dalam sabda Rasulullah telah dijelaskan:

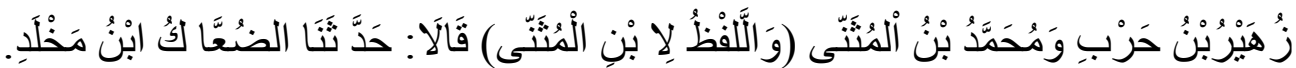

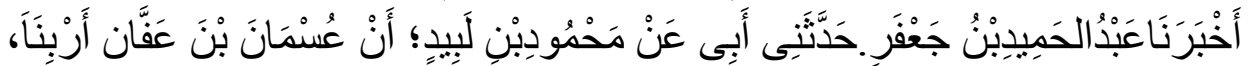

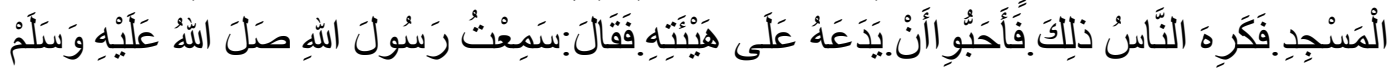

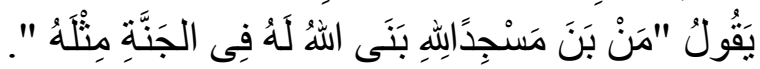

Artinya: "Zuhair Bin Harb dan Muhammad Bin Al-Mutsannah (lafadhnya menurut Al-Mutsannah), mereka berdua menerima dari Al-Dhuhak Ibnu Makhlad, dari Abdil Hamid Bin Ja'far, dari ayahnya, dari Mahmud Bin Labid. Berkata; sesungguhnya Utsman Bin Affan bermaksud memugar masjid, akan tetapi orang-orang tidak setuju rencana ini, mereka lebih menginginkan masjid itu di biarkan apa adanya. Maka Utsman Bin Affan berkata; saya telah mendengar Rasulullah SAW. Bersabda: "barang siapa membangun masjid semata-mata di niatkan karena Allah, maka Allah membangun masjid yang serupa kepada Nya di dalam syurga" (Al-Imam Abi Al-Husain Muslim Bin Al-Hajjaj Al-Qusyairiy Al-Naisabury, TTH).

\section{B. Pembentukan Karakter}

\section{Pengertian Karakter}

Karakter berasal dari bahasa latin "kharakter", "kharassein", "kharax", dalam bahasa inggris: character dan Indonesia "karakter", Yunani Character, dan charassein yang berarti membuat tajam (Abdul Majid dan Dian Andayani, 2012).

Secara bahasa, kata karakter berasal dari bahasa Yunani yaitu "charassein", yang berarti barang atau alat untuk menggores, yang dikemudian hari dipahami sebagai stempel/cap. Jadi, karakter adalah tabiat atau kebiasaan. Sedangkan menurut ahli psikologi, karakter adalah sebuah sistem keyakinan dan kebiasaan yang mengarahkan tindakan seorang individu. Karena itu, jika pengetahuan mengenai karakter seseorang itu dapat diketahui, maka dapat diketahui pula bagaimana individu tersebut akan bersikap untuk kondisi-kondisi tertentu. Dilihat dari sudut pengertian, ternyata karakter dan akhlak tidak memiliki perbedaan yang signifikan. Keduanya didefinisikan sebagai suatu tindakan yang terjadi tanpa ada pemikiran lagi karena sudah tertanam dalam pikiran, dan dengan kata lain, keduanya dapat disebut dengan kebiasaan (Sutarjo Adisusilo, 2013). 


\section{Macam-macam Karakter}

Sebelum masuk ke macam-macam karakter, di sini karakter yang akan ditumbuhkan atau dibentuk pada remaja yaitu karakter religius, jujur, toleransi, disiplin, kerja keras, harus kreatif, mandiri, komukatif, peduli lingkungan, peduli sosial dan bertanggung jawab atas tugas dan kewajibannya yang seharusnya dia lakukan. Itulah beberapa karakter yang harus dibentuk dan dimiliki oleh remajaremaja masjid.

Adapun macam-macam Karakter Remaja Masjid sebagai berikut:

a. Religius

Sikap dan perilaku yang patuh dalam melaksanakan ajaran agama yang dianutnya, toleran terhadap pelaksanaan ibadah agama lain, dan selalu hidup rukun dengan pemeluk agama lain.

b. Jujur

Perilaku yang didasarkan pada upaya yang menjadikan dirinya sebagai orang yang dapat dipercaya dalam perkataan, tindakan dan pekerjaan.

c. Toleransi

Sikap dan tindakan yang menghargai perbedaan agama, suku, etnis, pendapat, sikap dan tindakan orang lain yang berbeda dari dirinya.

d. Disiplin

Tindakan yang menunjukan perilaku tertib dan patuh pada berbagai ketentuan dan peraturan.

e. Kerja Keras

Perilaku yang menunjukan upaya sungguh-sungguh dalam mengatasi berbagai hambatan belajar dan tugas, serta menyelesaikan tugas dengan sebaik-baiknya.

f. Kreatif

Berpikir dan melakukan sesuatu untuk menghasilkan cara atau hasil baru dari sesuatu yang telah dimiliki.

g. Mandiri

Sikap dan perilaku yang tidak mudah tergantung pada orang lain dalam menyelesaikan tugas-tugas.

h. Rasa ingin tahu

Sikap dan tindakan yang selalu berupaya untuk mengetahui lebih mendalam dan meluas dari sesuatu yang dipelajari, dilihat dan didengar. 
i. Menghargai prestasi

Sikap dan tindakan yang mendorong dirinya untuk menghasilkan sesuatu yang berguna bagi masyarakat, dan mengakui, serta menghormati keberhasilan orang lain.

j. Bersahabat/ komunikatif

Tindakan yang memperlihatkan rasa senang berbicara, bergaul, dan bekerja sama dengan orang lain.

k. Cinta damai

Sikap, perkataan dan tindakan yang menyebabkan orang lain merasa senang dan aman atas kehadiran dirinya (Dirjen Dikdasmen Kemendiknas, 2010).

I. Peduli lingkungan

Sikap dan tindakan yang selalu berupaya mencegah kerusakan pada lingkungan alam di sekitarnya, dan mengembangkan upayaupaya untuk memperbaiki kerusakan alam yang sudah terjadi.

m. Peduli sosial

Sikap dan tindakan yang selalu ingin memberi bantuan pada orang lain dan masyarakat yang membutuhkan.

o. Tanggung jawab.

Sikap dan perilaku seseorang untuk melaksanakan tugas dan kewajibannya, yang seharusnya dia lakukan, terhadap diri sendiri, masyarakat, lingkungan (alam, sosial dan budaya), negara dan Tuhan Yang Maha Esa (Dirjen Dikdasmen Kemendiknas, 2010).

Dapat disimpulkan bahwa karakter tersebut sebagai cara berpikir dan berperilaku yang menjadi ciri khas tiap individu untuk hidup dan bekerja sama, baik dalam lingkup keluarga, masyarakat, bangsa, dan Negara. Jadi dengan adanya pendidikan karakter ini, mampu membangun aktifitas-aktifitas yang sangat positif kepada generasi muda kita yaitu sebagai penerus generasi bangsa. Karakter yang baik merupakan karakter yang memiliki aktifitas positif dan bermanfaat bagi diri sendiri dan juga bermanfaat bagi masyarakat sekitar.

\section{Karakter Religius}

\section{Pengertian Karakter Religius}

Kata dasar dari religius adalah religi yang berasal dari bahasa asing religion sebagai bentuk dari kata benda yang berarti agama atau kepercayaan akan adanya sesuatu kekuatan kodrati di atas manusia. Sedangkan religius berasal dari kata religious yang berarti sifat religi yang melekat pada diri seseorang. Religius sebagai salah satu nilai karakter dideskripsikan oleh Suparlan sebagai sikap dan 
perilaku yang patuh dalam melaksanakan ajaran agama yang dianut, toleran terhadap pelaksanaan ibadah agama lain, dan hidup rukun dengan pemeluk agama lain. Karakter religius ini sangat dibutuhkan oleh siswa dalam menghadapi perubahan zaman dan degradasi moral, dalam hal ini siswa diharapkan mampu memiliki dan berprilaku dengan ukuran baik dan buruk yang di dasarkan pada ketentuan dan ketetapan agama (Elearning Pendidikan, 2011).

\section{Macam-macam Nilai Religius}

Landasan religius dalam pendidikan merupakan dasar yang bersumber dari agama. Tujuan dari landasan religius dalam pendidikan adalah seluruh proses dan hasil dari pendidikan dapat mempunyai manfaat dan makna hakiki. Agama memberikan dan mengarahkan fitrah manusia memenuhi kebutuhan batin, menuntun kepada kebahagiaan dan menunjukkan kebenaran. Seperti yang ditetapkan pada Al-Qur'an Surah Al-Alaq ayat 1-5.

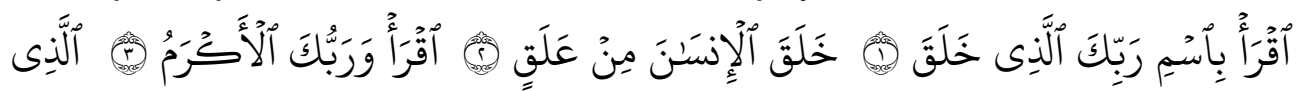

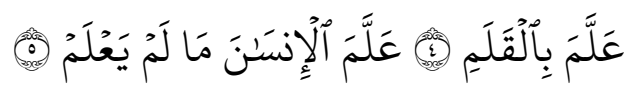

Terjemahan:

1. Bacalah dengan (menyebut) nama Tuhanmu Yang menciptakan.

2. Dia telah menciptakan manusia dari segumpal darah.

3. Bacalah, dan Tuhanmulah Yang Maha Pemurah.

4. Yang mengajar (manusia) dengan perantaran kalam.

5. Dia mengajar kepada manusia apa yang tidak diketahuinya.

Lima ayat diatas memerintahkan kepada manusia untuk melakukan pembacaan atas semua ciptaan Tuhan dengan berdasarkan ketauhitan.

Menurut Zayadi, sumber nilai yang berlaku dalam kehidupan manusia digolongkan menjadi dua macam yaitu:

a. Nilai ilahiyah

Nilai ilahiyah adalah nilai yang berhubungan dengan ketuhanan atau habul minallah, dimana inti dari ketuhanan adalah keagamaan. Kegiatan menanamkan nilai keagamaan menjadi inti kegiatan pendidikan. Nilai-nilai yang paling mendasar yaitu:

1) Iman, yaitu sikap batin yang penuh kepercayaan kepada Allah.

2) Islam, yaitu sebagai kelanjutan dari iman, maka sikap pasrah kepada-Nya dengan menyakini bahwa apapun yang datang 
dari Allah mengandung hikmah kebaikan dan pasrah kepada Allah.

3) Ihsan, yaitu kesadaran yang sedalam-dalamnya bahwa Allah senantiasa hadir atau berada bersama kita di manapun kita berada.

4) Taqwa, yaitu sikap menjalankan perintah dan menjauhi larangan Allah (Zayadi, 2001)

5) Ikhlas, yaitu sikap murni dalam tingkah laku dan perbuatan tanpa pamrih, semata-mata mengharapkan ridho dari Allah.

6) Tawakal, yaitu sikap yang senantiasa bersandar kepada Allah, dengan penuh harapan kepada Allah.

7) Syukur, yaitu sikap dengan penuh rasa terimakasih dan penghargaan atas nikmat dan karunia yang telah diberikan oleh Allah.

8) Sabar, yaitu sikap batin yang tumbuh karena kesadaran akan asal dan tujuan hidup yaitu Allah.

b. Nilai insaniyah

Nilai insaniyah adalah nilai yang berhubungan dengan sesama manusia yang berisi budi pekerti. Berikut adalah nilai yang tercantum dalam nilai insaniyah.

1) Silaturahim, yaitu menghubungkan tali kekerabatan, atau menghubungkan rasa kasih sayang antara sesama manusia.

2) Al-Ukhuwah, yaitu semangat persaudaraan.

3) Al-Musawah, yaitu pandangan bahwa harkat dan martabat semua manusia adalah sama.

4) Al-Adalah, yaitu wawasan yang seimbang.

5) Husnu Dzan, yaitu berbaik sangka kepada sesama manusia

6) Tawadlu, yaitu sikap rendah hati.

7) Al-Wafa, yaitu tepat janji.

8) Insyirah, yaitu lapang dada.

9) Amanah, yaitu bisa dipercaya.

10) Iffah atau ta'afuf, yaitu sikap penuh harga diri, tetapi tidak sombong tetap rendah hati.

11) Qawamiyah, yaitu sikap tidak boros.

12) Al-Munfikun, yaitu sikap kaum beriman yang memiliki kesediaan yang besar menolong sesama manusia.

\section{Tahap Perkembangan Religius}

Tahap perkembangan religius yang di kembangkan Moran seperti dikutip M.I Soelaeman sebagaimana dijelaskan berikut: 
a) Anak-anak

Dunia religius anak masih sangat sederhana sehingga disebut juga dengan the simply religious, pada saat itu anak memang belum dapat melaksanakan tugas hidupnya secara mandiri, bahkan sampai kepada yang paling sederhanapun. Dalam banyak hal anak harus mempercayakan dirinya kepada pendidiknya. Sifat anak adalah mudah percaya dan masih bersifat reseptif. Dalam dunia yang menurutnya belum jelas strukturnya, kesempatan untuk bertualang dalam dunia fantasi masih terbuka, karena dia belum dapat mengenal secara jelas realita yang dihadapinya. Oleh karenanya pendidikan agama kepada anak sering dengan metode cerita.

b) Remaja

Masa remaja merupakan masa peralihan dari anak menuju dewasa. Di samping perubahan biologis anak mengalami perubahan kehidupan psikologi dan kehidupan sosio-budayanya, dan yang lebih penting lagi dunia lainnya, dunia penuh penemuan dan pengalaman yang bahkan ditingkatkannya menjadi eksperimentasi. Tidak jarang dia mengahdapi ketidak jelasan, keraguan bahkan kadang-kadang seperti menemukan dirinya dalam dunia yang sama sekali baru dan asing. Dalam situasi seperti ini, tidak jarang dia harus terus menempuh langkahnya, yang kadang bersifat sejalan dan kadang-kadang berlawanan dengan apa yang telah terbiasa dilakukan seharihari, atau bahkan berlawanan dengan kebiasaan atau tradisi yang berlaku, sehingga dia tampak menentang dan menantang arus.

c) Dewasa

Pada saat ini seseorang mencapai tahap kedewasaan beragama, yakni mampu merealisasikan agama yang dianutnya dalam kehidupan sehari- hari atas dasar kerelaan dan kesungguhan dan bukan halnya peluasan diluar. Pribadi yang rela dan sungguh-sungguh dalam keberagamaannya sehingga akan menerima dan menjalankan kewajiban-kewajiban agama, maupun tugas hidupnya bukan sebagai sesuatu yang dibebankan dari luar, melainkan sebagai suatu sikap yang muncul dari dalam dirinya (Abdul Latif, 2007). 


\section{METODE PENELITIAN}

\section{A. Jenis Penelitian}

Penelitian yang penulis lakukan di Desa Waekasar Kecamatan Waeapo Kabupaten Buru ini menggunakan penelitian kualitatif, yakni prosedur penelitian yang menghasilkan data deskriptif berupa kata-kata tertulis atau lisan dari orang-orang dan perilaku yang diamati dan diarahkan pada latar alamiah dan individu tersebut secara menyeluruh (Lexy J. Moleong, 2009).

Sementara itu, Sugiyono mendefinisikan metode penelitian adalah cara ilmiah untuk mendapatkan data dengan tujuan dan kegunaan tertentu. Selanjutnya dalam pengertian yang luas, metode penelitian adalah cara-cara ilmiah untuk mendapatkan data yang valid, dengan tujuan dapat ditemukan, dikembangkan dan dibuktikan, suatu pengetahuan tertentu sehingga pada gilirannya dapat digunakan untuk memahami, memecahkan, dan mengantisipasi masalah (Sugiono, 2009).

\section{B. Kehadiran Peneliti}

Dalam penelitian ini, peneliti bertindak sebagai instrument sekaligus sebagai pengumpulan data, mengenai peranan remaja masjid arrahman dalam pembentukan karakter remaja yang religius di desa waekasar kecamatan waeapo kabupaten buru.

\section{Tempat dan Waktu Penelitian}

Penelitian ini akan dilaksanakan di desa waekasar kecamatan waeapo kabupaten buru, yang meliputi peranan remaja masjid arrahman dalam pembentukan karakter remaja yang religius di desa waekasar kecamatan waeapo kabupaten buru. Waktu yang digunakan peneliti untuk meneliti ini akan dilaksanakan sejak tanggal yang dikeluarkannya penelitian kurang lebih satu bulan pengumpulan data.

\section{Sumber Data}

Sumber data dalam penelitian ini didapatkan melalui observasi, wawancara dan dokumentasi. Adapun yang menjadi informasi dalam penelitian ini adalah: Kepala desa, satu orang ketua BKM masjid ArRahman, Ketua remaja masjid, Pembina remaja masjid, Sekretaris remaja masjid, Anggota remaja masjid.

\section{PEMBAHASAN}

\section{A. Peranan Remaja Masjid Dalam Pembentukan Karakter Remaja Yang Religius di Desa Waekasar Kecamatan Waeapo Kabupaten Buru.}

Masa remaja merupakan salah satu periode dari perkembangan manusia. Masa ini merupakan masa perubahan atau peralihan dari masa kanak-kanak ke masa dewasa yang meliputi perubahan biologis, 
perubahan psikologis, dan perubahan sosial. Remaja sering kali didefinisikan sebagai periode transisi antara masa kanak-kanak ke masa dewasa, atau masa usia belasan tahun, atau seseorang yang menunjukkan tingkah laku tertentu seperti susah diatur, mudah terangsang perasaannya dan sebagainya.

Jadi peranan remaja masjid Ar-Rahman sangatlah penting yaitu dengan pembentukan kepengurusan remaja masjid Ar-Rahman untuk menjalankan program kegiatan remaja masjid tersebut. Peranan remaja masjid disini lebih membuat remaja masjid lebih dekat dengan masjid, sebagai panutan atau contoh bagi yang lain atau bagi masyarakat sekitar, karena dulu sebelum adanya remaja masjid kegiatannya dilakukan oleh orang tua-tua, tetapi setelah ada remaja masjid, remaja yang lebih aktif seperti aktif dalam kegiatan, ikut kerja bakti, lebih berperan dalam kegiatan keagamaan seperti memperingati hari besar Islam dan menjadi partisipasi kemasyarakatan. Dengan begitu remaja dapat berperan aktif dalam kegiatan-kegiatan di masjid. Peranan remaja masjid dalam mengadakan program kerja sangat baik, salah satunya yang sudah terlaksana yaitu BKM merenofasi teras, program tersebut termasuk program remaja masjid untuk membantu BKM menyelesaikan pembangunan dengan cara kita menarik dana setiap panen satu rumah satu karung padi. Di program yang sudah tercapai alhamdulillah para remaja masjid sangat berperan dalam program tersebut dan sangat antusias dalam membantu. Tentu saja hal itu mendapat respon yang sangat baik dari pengurus masjid, ketua BKM, Pembina masjid serta dari masyarakat sekitar.

Peranan remaja adalah untuk memakmurkan masjid yaitu dengan upaya mendekatkan diri kepada Allah itu yang paling utama. Disamping itu mereka melakukan penyelenggaraan berbagai kegiatan yang bersifat ibadah, hubungan dengan Allah maupun hubungan sesama manusia yang bertujuan untuk meningkatkan iman dan taqwa, jasmani, rohani, kecerdasan dan kesejahteraan (Ahmad Muhsin Kamaludiningrat, 2010).

Jadi peranan remaja yang telah dilakukan oleh remaja masjid dalam pembentukan karakter yang religius yang sangat penting bagi remaja masjid untuk berperan aktif dalam melaksanakannya adalah sebagai berikut:

a) Mengaji bersama

b) Peringatan hari besar Islam

c) Rutinan berjanjen atau sholawat

d) Kerja bakti 
e) Santunan anak yatim

f) Bakti sosial

g) Peringatan 17 Agustus

Oleh karena itu seorang remaja harus memiliki karakter yang lebih baik agar dapat menjadi contoh yang baik untuk remaja lainnya, karena adanya peranan remaja dalam pembentukan karakter yang religius tersebut remaja dapat memiliki kemampuan untuk memahami dan mengenal ilmu agama lebih dalam, saling peduli, saling menghormati dan menghargai, dan memiliki sikap kebersamaan.

Manfaat dari pembentukan karakter yang religius ini dapat mendekatkan remaja dengan masjid, belajar tentang agama dan melaksanakan ibadah kepada Allah SWT, bersosialisasi dengan masyarakat, serta melakukan hal-hal yang baik. Adanya harapan merupakan hal yang baik yang diinginkan oleh semua pihak dan seluruh masyarakat agar remaja tetap berperan penting disetiap program-programnya dan selalu kompak dalam menjalankan program kegiatan. Jadi harapan dari adanya peranan remaja masjid ini menjadikan yang terbaik, karena peran remaja masjid sangatlah penting agar dapat menjadi penerus, remaja masjid tetap istiqomah, dan remaja tetap terlihat kinerjanya, remaja juga tetap berpartisipasi untuk masyarakat dan memakmurkan masjid.

B. Kegiatan Yang Menjadi Pembentukan Karakter Remaja Masjid ArRahman di Desa Waekasar Kecamatan Waeapo Kabupaten Buru.

Berdasarkan hasil wawancara peneliti ketika berada di Masjid ArRahman Desa Waekasar terkait peranan remaja masjid dalam pembentukan karakter remaja yang religius ini khususnya dalam melakukan kegiatan yang dapat membentuk karakter remaja menunjukkan bahwa, remaja masjid memiliki peran yang sangat baik dalam melakukan atau menjalankan semua program kegiatan tersebut. Banyak remaja masjid yang mengaku senang dengan adanya kegiatankegiatan remaja masjid ini, karena mereka dapat lebih dekat dengan masjid, lebih tau tentang agama, dan ditambah dengan adanya kajian rutin mereka dapat memahami ilmu agama dan kesadaran dalam beragama.

Kegiatan-kegiatan remaja masjid Ar-Rahman yang dapat membentuk karakter remaja yaitu, seperti kegiatan Maulid Nabi Muhammad SAW, Isra' Mi'raj, menyambut bulan Ramadhan, tahun baru hijriyah, santunan anak yatim, mengaji bersama, Nuzulul Qur'an, halal bihalal, rutinan berjanjen atau sholawat, kerja bakti, bakti sosial, kajian rutin/Pengajian rutin, dan latihan rebana. 
Walaupun dalam proses kegiatan selalu berjalan lancar, adapun kendala yang dihadapi yaitu kendala dalam hal masalah dana. Tetapi adanya masalah dalam melaksanakan kegiatan tersebut remaja masjid dapat mengatasinya dengan baik.

Jika melihat dari kegiatan yang sudah direncanakan dan dilaksanakan, hambatan yang dialami pada waktu kegiatan berlangsung dan pendapat masyarakat yang ikut dalam kegiatan tersebut maka dapat disimpulkan bahwa remaja Masjid Ar-Rahman telah menunjukkan keberhasilan dalam membentuk karakter remaja di Waekasar dengan keefektifan kegiatan-kegiatannya. Hal ini dapat diketahui, yaitu:

a. Adanya kemajuan beribadah dalam diri remaja sekaligus masyarakat yang aktif sholat berjama'ah di masjid dan banyak beramal.

b. Antusias warga dalam mengikuti semua kegiatan remaja masjid.

c. Adanya rasa kesadaran beragama yang dimiliki oleh remaja dengan mewujudkan sholat yang tepat, dan memperbanyak ibadah kepada Allah.

d. Melihat butuhnya remaja terhadap kegiatan yang dirasa dapat membawa kemajuan dalam beribadah kepada Allah, hubungan dengan sesama manusia, serta hubungan dengan alam.

e. Tidak ditemui adanya kesenjangan dalam masyarakat, karena masyarakat menjalin hubungan antar umat beragama ataupun antar agama dengan baik.

f. Masyarakat memiliki sikap tenggang rasa ataupun sikap toleransi yang sangat baik terhadap sesama dan warga yang berbeda keyakinan, dengan tidak mencampuri agama orang yang berlainan keyakinan dan tidak mencampur adukkan agama Islam dengan agama yang lain.

Dengan demikian kegiatan keagamaan yang diadakan dan dilaksanakan oleh Remaja Masjid Ar-Rahman dalam pembentukan karakter dimasyarakat pada dasarnya telah sesuai dengan teori yang telah dijelaskan sebelumnya yaitu: kegiatan ibadah khusus (sholat lima waktu, sholat tarawih, dan lain sebagainya), kegiatan sosial (santunan anak yatim, pembagian daging qurban, pembagian zakat), kegiatan pendidikan (banjari, diba' dan lain-lain), dan kegiatan dakwah (peringatan hari besar Islam, peringatan hari besar nasional, pengajian rutin). Dengan adanya kegiatan-kegiatan tersebut maka terciptalah kerukunan di masyarakat antara sesama agama, beda agama, juga dengan pemerintah, dan keaktifan beribadah masyarakat pun menunjukkan kemajuan. 


\section{PENUTUP}

Berdasarkan hasil penelitian dan pembahasan, maka dapat disimpulkan sebagai berikut:

1. Peranan remaja Masjid Ar-Rahman dalam pembentukan karakter remaja yang religius di Desa Waekasar Kecamatan Waeapo Kabupaten Buru cukup baik dalam melakukan program kegiatan, dan remaja sangat berperan aktif dalam kegiatan yang dilakukan tersebut baik itu kegiatan di lingkungan masjid, dan juga memiliki kepedulian terhadap lingkungan di luar masjid. Jadi dengan remaja berperan dalam program kegiatan tersebut dapat membentuk karakter yang religius. Peranan remaja masjid sendiri adalah dengan mereka ikut serta dan berperan dalam kegiatan mengaji bersama, peringatan hari besar Islam, rutinan berjanjen atau sholawat, latihan rebana, ikut kerja bakti, bakti sosial, dan remaja berperan dalam peringatan 17 Agustus atau hari Nasional.

2. Kegiatan remaja Masjid Ar-Rahman yang mengarah pada pembinaan kehidupan beragama hanya tertentu saja, yaitu: a. kesadaran beragama yaitu mengaji bersama, rutinan berjanjen dan sholawat rabu malam, latihan rebana, santunan anak yatim pada bulan ramadhan, dan membaca surat Al-Fatiha bersama secara bersambung, b. kerukunan antar agama dalam kegiatan remaja masjid tidak aada, c. kerukunan sesama umat beragama yaitu jam'iyah diba' dan umat Islam, d. kerukunan dengan pemerintah yaitu dengan melakukan kegiatan Peringatan Hari Besar Islam.

\section{DAFTAR PUSTAKA}

[1] Abdul Majid dan Dian Andayani, Pendidikan Karakter Perspektif Islam, Bandung: PT Remaja Rosdakarya, 2012.

[2] Adisusilo, Sutarjo. Pembelajaran Nilai Karakter, (akarta: PT. Raja Grafindo Persada, 2013.

[3] Al-Imam Abi Al-Husain Muslim Bin Al-Hajjaj Al-Qusyairiy AlNaisabury, Shahih Muslim, Jilid 1, Kitab Al-Masajid Wa Mawadhi' Al-Shalat, Bab Fadhlu Bina'i Al-Masajid Wa Al-Hatsu Alaihi,Beirut: Dar Al-Turast Al-Arabiy, TTH.

[4] Darajat, Zakiah. Pendidikan Agama dan Pembinaan Mental, Bandung: Bulan Bintang, 1973.

[5] Dirjen Dikdasmen Kemendiknas, Pembinaan Pendidikan Karakter, Jakarta: Dirjen Dikdasmen Kemendiknas, 2010.

[6] Elearning Pendidikan, 2011, Membangun Karakter Religius Pada Siswa Sekolah Dasar, dalam (http://www.elearningpendidikan.com).

[7] Hasil-hasil Ketetapan Masyarakat Nasional XI, Badan 
Komunikasi Pemuda Remaja Masjid Indonesia, Jakarta: Kencana, 2009.

[8] Kamaludiningrat, Ahmad Muhsin. "Meningkatkan peran dan Fungsi Masjid dalam Dakwah dan Pembinaan Masyarakat Madani Beriman dan Bertaqwa", Jogjakarta: Jurnal Ulama, 2010.

[9] Latif, Abdul. Pendidikan Berbasis Nilai Kemasyarakatan, Bandung: Refika Aditama, 2007.

[10] Mapiare, Andi. Psikologi Remaja, Surabaya: Usaha Nasional, 1982.

[11] Moleong, Lexy J. Metode Penelitian Kualitatif, Bandung : Remaja Rosdakarya, 2009.

[12] Ratu Perwiranegara, Alamsyah. Pembinaan Kehidupan Beragama Indonesia, Jakarta: Departemen Agama RI, 1980.

[13] Safri Harahap, Sofan. Manajemen Masjid, Yogyakarta: Dhana Bhakti Prima, 1996.

[14] Sugiono, Metode Penelitian Kuantitatif dan Kualitatif $R \& D$, Jakarta : CV.Alfabeta, 2009.

[15] Syafri Harahap, Sofyan. Manajemen Masjid Dalam Meningkatkan Kesejahteraan Ummat, Surabaya: Pustaka Quantum Prima, 2001.

[15] Zayadi, Desain Pendidikan Karakter, Jakarta: Kencana Pramedia Group, 2001. 